\title{
BRICS as the Subject of Study of International Relations Theory ${ }^{1}$
}

\author{
A. Sergunin, F. Gao
}

Alexander Sergunin - Doctor of Political Science, Professor, Department of International Relations Theory \& History, St. Petersburg State University; 1/3 Smolny St., St. Petersburg, 191060, Russian Federation; E-mail: a.sergunin@spbu.ru.

Fei Gao - Professor, Vice-President, Dean of Academic Affairs, China Foreign Affairs University, 24 Zhanlan Rd., Beijing 100037, People’s Republic of China; E-mail: fgao@cfau.edu.cn

\begin{abstract}
This article examines the phenomenon of the BRICS grouping of Brazil, Russia, India, China and South Africa from the perspective of several theories of international relations; in particular, power transition theory, soft power and peaceful coexistence concepts, the theory of "global regionalism" and status theories are reviewed. Each explains both the BRICS phenomenon and the role of this integration association in the present-day international relations system. It is concluded that, depending on research objectives and the way it is applied, each theory - despite limitations - has explanatory power. Together they create an interdisciplinary basis for studying complex phenomena such as the BRICS.

A number of modern theories hold that, along with the pursuit of purely material and pragmatic interests, the BRICS countries actively use this integration association to strengthen their positions in the world arena and elevate their international status.

It is also concluded that the BRICS succeeded in creating an image of an alternative model of world order based on the principles of cooperation, mutual respect and balance of interests, rather than mandate, discrimination and hierarchy. It is premature to make a statement that a principally new type of interstate relations or an international institution has been created within the BRICS framework. At the same time, it is also certain that some positive experience has already been accumulated in the framework of this forum, and that this association offers good prospects for the future. For this reason it is of considerable interest for international relations theory.
\end{abstract}

Key words: BRICS; international relations theory

For citation: Sergunin A., Gao F. (2018) BRICS as the Subject of Study of International Relations Theory. International Organisations Research Journal, vol. 13, no 4, pp. 55-73 (in English). DOI: 10.17323/19967845-2018-04-03.

${ }^{1}$ The editorial board received the article in March 2018.

This research was made in the framework of the project supported by the St. Petersburg State University (IAS code 17.37.226.2016). 


\section{Introduction}

Since its inception, the BRICS grouping of Brazil, Russia, India, China and South Africa has attracted the attention of the academic community. Despite its relatively young age, the BRICS already has quite a rich historiography in which several kinds of work can be distinguished. A number of contributions are devoted to the history of the emergence and formation of the BRICS [Korshunov, 2013; Toloraya, 2011 and 2014; Lukyanov, 2011; Nadkarni, Noonan, 2013; Simha, 2013; Wolfe, 2008]. In particular, researchers were interested in the motives of the parties when they joined the association. This type of research was characteristic of the early stage in the study of this phenomenon.

The most common type of research on the BRICS is by economists devoted to the study of the economic potential of individual BRICS countries, their impact on global economic and financial processes, and their cooperation with each other in the fields of economics, trade, finance, environmental protection and so on [Toloraya, Yurtaev, Ajdrus, 2016; Leksyutina, 2017; Glinkin, 2014; Toloraya, 2014; Toloraya, Chukov, 2016; Nadkarni, Noonan, 2013]. In particular, a wide range of studies covers the ability of the BRICS countries to attract foreign direct investment as one of the reasons for their dynamic development. Economists also focus on the comparison of the aggregate economic power of the Group of $7(\mathrm{G} 7)$ and the BRICS group, and on the correlation of these two informal groups [Korshunov, 2013; Okuneva, 2012; Panova, 2013; Kuzmin, 2013].

A relatively small amount of research is devoted to the development and prospects of the BRICS as a special mechanism of interstate cooperation (including its ability to stimulate changes in the system of global economic governance) [Toloraya, Yurtaev, Ajdrus, 2016; Leksyutina, 2016; Leksyutina, 2017; Glinkin, 2014; Okuneva, 2012; Toloraya, 2011; Toloraya, 2014; Toloraya, Chukov, 2016; BRICS: New Configurations of Global Power, 2015; Fulquet, 2015].

Research that attempts to interpret the BRICS theoretically as the germ of an alternative economic and political world order is even less common [Konyshev, Nocen, Sergunin, 2017; The BRICS and Coexistence, 2015; Fulquet, 2015; Stuenkel, 2014a; Stuenkel, 2014b].

Importantly, the BRICS phenomenon requires not only applied analysis, but also theoretical comprehension. Theoretical reflection helps to avoid the known limitation of a purely empirical explanation of the nature, mechanisms and perspectives of the evolution of the BRICS. Is what arises before our eyes another institution of interstate cooperation which fits into a number of already existing structures, or is it a fundamentally different model of relations that can seriously change the trends of world politics? What drives the policies of the BRICS countries? Can the BRICS group become an alternative to the domination of the western powers, which is formalized in the present system of international institutions and unions? Will this institution provide fundamentally new conditions which may lead to the development of international cooperation as opposed to continued power politics? Can the BRICS be considered a new mechanism of global governance, or is it nothing more than a temporary intergovernmental arrangement?

Without pretending to answer all of these questions, this article examines how the main international relations theories (IRTs) interpret the BRICS phenomenon. The task is not only to determine the advantages and disadvantages of these theories, but also to evaluate their heuristic potential for studying such a complex phenomenon as the BRICS. 
This study starts with the assumption that the BRICS is a promising integration association which so far has no formalized institutional or organizational nature and which is therefore best understood as an interstate discussion forum rather than a full-fledged international organization. However, the BRICS has every chance of becoming an influential institution of global governance, operating according to rules different from those adopted in organizations controlled by the most developed countries of the world.

It is this dynamic and multidimensional nature of the BRICS that creates particular difficulties for various IRTs trying to explain and predict the further development of this association. Of the many theories involved in the study of international institutions, this article examines those that, on the one hand, are the most influential in the framework of their respective IRT paradigms and, on the other, represent the most interesting conceptual interpretations of the BRICS.

\section{Power Transition Theory}

Among western experts, the power transition theory (PTT) first proposed by A. Organski is the most popular approach [Organski, 1958]. PTT developed within the framework of the neorealist paradigm and is based on the assumption that changes in the balance of power in world politics happen all the time. This theory considers conflicts and wars to be the results of the growing influence of states competing with the dominant powers. In this regard, all states are divided into two groups: those which support the status quo and "revisionists." Powerful and influential states, such as the United States, enjoy the advantages of the established world order and fall into the status quo category, while states dissatisfied with their place and role in international relations are considered revisionists. They favour radical changes in the existing international order. And here, Russia and China are the primary focus of attention.

According to PTT, present-day Russia is a typical revisionist state. Experts from the Heritage Foundation, a conservative American think tank, see in this regard several problems that Russia creates for the United States and its allies. In their opinion, the Putin regime is challenging democratic values, as manifested in a combination of disrespect for citizens' political, civil and economic rights and a weak economy. The restoration of Russia' s military power and its political and diplomatic influence creates a strategic challenge to the West and its allies. In particular, the threat to U.S.-friendly countries - Ukraine, Georgia, Poland, the Baltic States, Finland and Sweden - is growing. The problem is amplified by Russia' s cooperation with "rogue states," including Syria, Iran and North Korea [Carafano, 2015]. Similar evaluations are made of the policies of the People's Republic of China (PRC) [Cheng, 2016].

If revisionists are considered to be a source of destabilization in the world order, and in this sense if their role is associated with negative consequences, then the actions of the dominant (status quo) states are considered positive because they perform protective system functions. Therefore, cases such as the military intervention by the North Atlantic Treaty Organization (NATO) in Kosovo and the actual division of Yugoslavia, U.S., European and global missile defense projects, NATO' s expansion to the east, sponsorship of the "colour revolutions" in the post-Soviet space, military assistance to Taiwan from the U.S., 
and Washington's demonstrative pursuance of the free navigation principle in the South China Sea are not considered to pose a threat to Russia or the PRC [Carafano, 2015, p. 3].

Among PTT proponents, the sources of revisionist behaviour are evaluated differently. More moderate experts believe that sources of such behaviour lie in Russia's and the PRC' s failure to build democracy domestically, which prevents them from fully integrating into the international economy and institutions of global governance [Granholm, Malminen, Persson, 2014, pp. 10, 26-9]. A more radical point of view is that, due to Russia's and China's historical peculiarities, they are fundamentally unable to integrate with the West [Carafano, 2015, p. 3].

It is not incidental that the policies of individual BRICS countries are assessed differently. One group of experts sees the BRICS as an instrument allowing some of its members to secure their great power status and counterbalance western institutions at the regional and global levels. However, the majority of the expert community sees the PRC' $s$ and Russia' s roles differently: while China is viewed as a rising power, Russia is seen as being in crisis due to economic problems. To respond to these challenges different variants of containment policy are suggested.

However, not all power transition theorists see Russia and China as revisionist powers. Some take the view that even Putin's Ukraine policy can be seen as a status quo strategy that aims to secure Russia' s influence in the post-Soviet space and counterbalance NATO' S eastward expansion [Charap, Shapiro, 2014; Kuhn, 2015]. A similar evaluation can be made at the global level regarding the skepticism of the PRC and Russia regarding United Nations (UN) reform. However, other BRICS participants (Brazil and India), on the contrary, express their interest in reform in the hope that their status will be elevated in the UN security council.

"Status quo" proponents believe that the problem is that BRICS countries were not integrated on an equal footing into the international security system which has gradually emerged in the post-Cold War era. The West crossed some "red lines" which were established by Russia in the post-Soviet space. For example, the August 2008 RussianGeorgian armed conflict was a clear manifestation of such western policy. The Ukrainian crisis, which started in 2014 and continues to this date, is another example. When the Kiev authorities who came into power after the removal of the Yanukovich regime openly stated their intention to join the European Union (EU) and NATO, Moscow reintegrated Crimea into Russia and supported pro-Russian rebels in the Donbass.

In this expert group' s opinion, Russia' s policy is determined not only by its geopolitical but also by its geoeconomic interests related to the competition of Moscow's integration project in the post-Soviet space with Euro-integration plans such as the EU's Eastern Partnership programme [Collins, 2015, p. 3; Sergunin, 2013]. Proponents of this point of view believe that it is better to cooperate rather than confront Russia. The same approach is suggested with regard to China.

Despite a number of advantages, PTT also has many disadvantages. This theory was more applicable to the period of the Cold War, when two superpowers were interested in maintaining the status quo because of the threat of mutual destruction in the event of war. The present-day international relations system, including its structure, is still in its formative phase. In this context, PTT can explain little about the behaviours of the BRICS states. 
PTT does not take into account the existence of a third type of state - the reformist state which does not fully agree with the world structure, but prefers not to radically change the "rules of the game." Instead, it tries to adapt them to the changed conditions in order to make them more fair and comfortable for all participants of international relations. Quite often, these states do not act as revisionists, but rather as supporters of the status quo by demanding that the previously established rules of the game and international legal norms are observed. For example, the BRICS countries firmly oppose any attempts to revise the UN Charter regarding the use of military force and the principles of inviolability of state sovereignty and noninterference in the internal affairs of sovereign states (as opposed to the western doctrine of "humanitarian intervention") [Konyshev, Kubyshkin, Sergunin, 2015; Sergunin, 2010].

At the same time, the BRICS participants are unhappy with the current order of things, in which a small group of highly developed countries dominate and try to dictate rules to the rest of the world. The BRICS countries would like to change the existing world order, but in an evolutionary rather than radical (revolutionary) way, which justifies considering them reformist rather than revisionist powers [Hansen, Sergunin, 2015]. The BRICS countries are also striving to cultivate an image of themselves not as spoilers or revisionists, but as reformers of the existing unfair international relations system. They are trying to create alternative financial institutions that would help prevent a new global financial and economic crisis [Mikhailenko, 2016; The Moscow Times, 2014]. As recent BRICS documents show, this forum also assumes responsibility in other areas of world politics - the environment, the fight against the negative effects of climate change, international terrorism, cybercrime and the reform of leading international organizations, including the UN [BRICS, 2017]. In general, the BRICS countries show a desire to build more efficient models of world order, and they do it on a nonconfrontational basis [Mikhailenko, 2016].

Thus, if supporters of PTT want this theory to better respond to modern realities and retain its explanatory power in current conditions, they need to revise the typology of states they use and supplement it with a new ("reformist") type of power.

\section{"Soft Power"}

The accumulation of "soft power" as understood by neoliberals is attractive to the BRICS countries for a number of reasons. First, it can help them overcome their negative image in the West which resulted from a series of international conflicts (between Russia and Georgia and Ukraine, between China and its neighbours in the South China Sea and between India and Pakistan). Second, it can help to make methods of geopolitical and geoeconomic expansion more effective.

In BRICS countries, soft power is interpreted in different ways, sometimes departing from the initial meaning advanced by Joseph Nye, who defined soft power as based on the power of attractiveness. In reality, however, Russia's and China's policies are dominated by pragmatic interests that not always take into account their partners' preferences. In Nye's view, this is unacceptable to their partners and may even provoke a hostile reaction to their soft power initiatives [Nye, 2013].

Russia and China view soft power only as an auxiliary tool to protect their national interests, while many experts rightly see in this concept a broader reading of security which 
includes a nonmilitary component in the concept of security and relies more on cooperation with partners [Gronskaya, Makarychev, 2010; Tsygankov, 2013; Sergunin, Karabeshkin, 2015; Tsygankov, 2012].

Some specifics in the BRICS countries' interpretations of the soft power concept should be noted. First and foremost, this is an umbrella concept which covers other closely related concepts - public diplomacy, peoples' diplomacy, the humanitarian dimension of politics and NGO-diplomacy. Among soft power instruments, financial tools (especially in the case of China), cultural cooperation, ethnic diasporas, and educational and religious institutions are preferable. The BRICS countries established special bodies for soft power implementation (for example, the PRC's Confucius Institutes, Russia's Rossotrudnichestvo, "Russian World," and Gorchakov and Andrei Pervozvanny foundations among others).

In these countries, soft power policy is controlled and directed to a large extent by the government and this makes it less flexible. In Nye's opinion, Russia and the PRC have make a mistake by underestimating the importance of civil initiatives, while in the U.S. the main sources of soft power are universities, cinema and pop culture rather than the government [Nye, 2013]. The government should multiply the effect of the activities of civil society institutions rather than limit them.

At the same time, the use of soft power strategies by BRICS countries has some peculiarities and advantages. First, the BRICS demonstrates the inclusive nature of its cooperative format. BRICS countries are located on different continents and have different political systems, levels of economic development, histories and cultural traditions. However, the BRICS shows that different countries are able to cooperate and be successful. Second, in contrast with the West, over the last 20 years the BRICS has demonstrated its success in the field of socioeconomic development. In 1990-2015, the share of western countries in world gross domestic product (GDP) fell from $78.7 \%$ to $56.8 \%$, while the share of emerging economies increased from $19.0 \%$ to $39.2 \%$ [UN, n.d.]. Third, India, China and Russia have long histories and unique cultures which have substantially enriched world culture.

Generally speaking, BRICS countries use soft power in their own way, trying to avoid copying the western experience and going beyond Nye's interpretation of the soft power concept. In practical terms, they stick to an instrumentalist and pragmatic approach oriented toward important state political aims. It should be noted, however, that these states' doctrinal documents and academic communities have not yet developed a clear terminology with regard to soft power and this negatively affects both the theoretical understanding and effectiveness of this political instrument. At the same time, BRICS countries have a tremendous soft power potential which can strengthen their positions in the traditional spheres of influence, especially if their policies are attractive in Nye' s sense.

\section{Peaceful Coexistence Theory}

The peaceful coexistence concept was and is one of the distinctive characteristics of Russia' s, India's and China's foreign policies. It was developed - in various forms - by representatives of neoliberalism, globalism and neorealism. In Russia, it emerged in the initial period of the Soviet state, during a time in which it had to operate in a hostile capitalist environment. Peaceful coexistence did not stop confrontation with world capitalism but, since the Soviet leadership led by Vladimir Lenin felt itself isolated, it preferred to transform its 
confrontation with the West from the military to nonmilitary spheres. In Lenin's interpretation, avoiding armed conflict did not mean peace with capitalism, which was seen as hostile by definition. On the contrary, he considered peaceful coexistence to be the transformation of war into other forms of rivalry, first and foremost economic competition, that could demonstrate the advantages of the socialist development model [Lenin, 1970, p. 78].

In the USSR, this concept dominated the post-World War II period until Mikhail Gorbachev' s "perestroika," after which it became configured. However, it turned out that with the end of the Cold War the concept was no longer interesting to Russian elites who had failed to join international institutions on equal footing. The concept itself thus disappeared from Russian doctrinal documents.

China, in contrast with Russia, never abandoned the peaceful coexistence concept and elevated it to the status of a fundamental international relations principle after the 1999 NATO military intervention in Kosovo. According to Beijing, this concept includes postulates such as respect for national sovereignty and territorial integrity, noninterference in domestic affairs, equality of states in international relations and the leading role of the UN in world politics because of its universal nature [Russian Gazette, 1999]. China suggested peaceful coexistence as an alternative concept to American "neo-interventionism."

In India, the peaceful coexistence concept was transformed from its initial version into the Vasudhaiva Kutumbakam concept ("the whole world as one family") which rejected the very idea of hegemony [Gupta, Chatterjee, 2015, pp. 115-24].

In formal terms, Brazil's foreign policy doctrinal documents stopped mentioning the peaceful coexistence concept in the 1960s; however, the state's real international policies were in line with this principle. This included the establishment of bilateral cooperative links with other countries regardless of their political and economic regimes, respect for national sovereignty, and the development of multilateral cooperation [Abdenur, 2015].

In South Africa, the peaceful coexistence principle in the form of the Ubuntu concept was formally acknowledged in the 2011 white book on foreign policy. This concept was defined as "respect for all states, nations and cultures," while the understanding of national security was based on the acknowledgement of the priority of human security [Mandrup, Smith, 2015, pp. 150-1].

The interest of BRICS countries in the peaceful coexistence concept can be explained by several objective factors. At certain points, these states started to express their discontent with the existing model of relations with the West which they considered to be unviable and unacceptable. For example, Russia faced the failure of several ideas and models, such as the "comprehensive security" concept (Mikhail Gorbachev), Russia as a "younger partner" of the West (Boris Yeltsin) and "strategic partnership" with the U.S. (two initial presidencies of Vladimir Putin and Dmitry Medvedev's administration). The West had no respect for BRICS countries' regional and global interests; it heavily criticized them for "authoritarianism," a democracy deficit and human rights violations. Such western policies forced not only BRICS countries but also other states - which did not want to accept the "golden billion' s" dictate - to realize that different/alternative social development models are preferable. In their view, the peaceful coexistence concept could only be helpful in building relations between states of different types.

It should be noted that presently the peaceful coexistence concept has a different meaning as compared to the Cold War era because the antagonistic confrontation between 
the two sociopolitical systems has ended. BRICS countries do not aim to defeat the world capitalist system as was the case in the socialist camp in the past. They just want integration into the world economy and global governance systems on an equal basis. In geopolitical terms, Russia has lost its superpower status and cannot compete with other poles of power as it could previously, while other BRICS countries avoid global confrontation with the United States altogether.

The updated interpretation of the peaceful coexistence concept by the BRICS countries can be summarized as follows:

- countries with different economic and sociopolitical systems can coexist peacefully;

- the dominance of one or several countries in world politics is unacceptable;

- preference should be given to tools of "soft power," while military force should be only an extreme means, and;

- cooperation should occur with international political and economic structures created by the West, even despite the continuing contradictions with them.

The peaceful coexistence concept has not yet entered the permanent political lexicon of the BRICS countries (with the exception of the PRC). This is partly due to a kind of "allergy" to Marxist-Leninist terminology. But in one form or another, this concept is present in their foreign policy arsenals [The BRICS and Coexistence, 2015; Sergunin, 2016, pp. 37-45].

However, as noted by a number of researchers, the peaceful coexistence concept cannot embrace the entire complexity and diversity the BRICS and its international activities. It partly sheds light on the motivation and certain features of "the five" in the international arena. But it cannot give a full explanation as to why these countries have united in a group, and what long-term strategic goals they pursue. It also cannot explain where the limitations of the peaceful coexistence policy are, beyond which the BRICS countries are willing to resort to force, and what factors induce them to take such sometimes risky steps [The BRICS and Coexistence, 2015; Sergunin, 2016, pp. 37-45].

More generally, all of the theories and concepts discussed above suffer from one significant shortcoming: being based on the principles of rationalism, i.e., a perception of the BRICS countries as purely rational actors seeking to maximize their benefits and build their activities in a pragmatic way, they are unable to explain the emotional, unpredictable, illogical actions taken by these states which not only do not benefit them, but sometimes even harm their interests and cause significant damage.

\section{Status Theories}

Status theories are particularly useful for those cases in which the policies of the BRICS countries are evaluated by partners as being emotional, irrational and unpredictable. Such policies do not fit into the theories built on the principle of rationalism, including the PTT, as well as the concepts of peaceful coexistence and soft power. Status theories address policy motives related to self-esteem, reputation, honour and dignity, fame, sympathy, and other emotional and psychological categories that introduce an element of unpredictability into the political behaviour of leaders and social groups. The first works on the correlation of conflicts and state status underachievement were published in the late 1960s-early 1970s [Midlarsky, 1969; Wallace, 1973]. 
The return of status theories occurred in the 2000s, when representatives of various theoretical paradigms started to pay attention to them again. Schools such as neorealism and neoliberalism mainly focused on problems of survival and economic viability, considering the state's status to be a derivative of its military and economic power. For postpositivist schools, initially, status was also not an important analytical category, although it was scholars in these schools who paid serious attention to the psychological aspects of political behaviour. For example, theorists of social constructivism believe that identity and norms are the driving forces of politics rather than considerations of status or prestige [Onuf, 2013].

For the BRICS countries, the status-related issues were first raised in connection with the discussion of modern Russia's goal to strengthen its significance in world politics and return to its former position as a great power [Kanet, 2010; Kuhn, 2015; Larson, Shevchenko, 2010; Neumann, 2005; Neumann, 2007]. This turn in Russia' s policies was related to President Vladimir Putin's decision to more decisively defend its interests. The Russian president perceived the collapse of the USSR as "the greatest geopolitical catastrophe of the 20th century." The status of Russia had lost certainty: while its nuclear potential and the permanent seat on the UN Security Council guaranteed it a place among the most influential countries, by other measures it had been reduced to the status of a peripheral state. In this regard, some western experts evaluated the state of Russian elites as "status panic" [Forsberg, Heller, Wolf, 2014; Hansen, Sergunin, 2015, p. 94; Smith, 2014].

Interest in status theories has been fueled by discussions about the nature of the conflicts between Russia and Georgia (2008) and Ukraine (2014). Some researchers, in the tradition of constructivism and poststructuralism, see these conflicts as manifestations of Russia's fear of finally losing its great power status. Moreover, this motivation may be even more important than concerns about security or economic well-being [Sergunin, 2014]. Some authors go even further, claiming that Russia's status-oriented foreign policy has deep historical roots, because for centuries Moscow has sought to prove its high status in Europe [Neumann, 2005].

With China, which previously did not have the status of a great power, the situation is somewhat different. Its rapid economic growth in the post-Cold War era has meant that the former character of China's political and economic relations with the West no longer holds. At first, China sought to achieve the status of a great power by adapting to capitalist norms, but it was never accepted as an equal in the western community. Then Beijing took a more competitive position, but not in a confrontational way. It managed to positively change its image in the eyes of the West. The new image is based on the premise that China is a state that does not seek hegemony, but expects a respectful attitude from its international partners which corresponds to its new status.

India and Brazil also strive for the status of great power, relying on their large territories and populations, economic and military potential, and international authority. Their behaviour is of a symbolic nature and is aimed at increasing respect from other states [Mikhailenko, 2016; Larson, Shevchenko, 2010, p. 70]. For instance, the Brazilian president's statement on hosting the 2016 Summer Olympic Games exemplifies such symbolism: the choice of Brazil as the host of the games elevated its status from second-class to first-class country. South Africa does not have the ambition to become a great power, but at the regional level it seeks to play a leading role. 
Politically, states seeking to improve their international status may try to join the leading group of states (mobility strategy), enter into a competition with leaders (competition strategy) or try to achieve advantages in any field (creativity strategy). The choice of a specific or combined strategy depends on the degree of openness of the international hierarchy and the degree of closeness of the values of socioeconomic and cultural development.

For example, since the end of the Cold War, the BRICS states have embarked on liberal democratic reforms to enter the economic and political institutions of the West, such as the International Monetary Fund, the World Trade Organization, the Council of Europe and the G7. At the same time, the closed nature of organizations such as the EU or NATO prompts China and Russia to move to a strategy of competition [Larson, Shevchenko, 2010, pp. 72-3]. On the path of creative strategy, Russia is trying to rely on the neoconservative ideas of collectivism, spirituality and orthodoxy as opposed to the individualism, materialism and liberal morality of the West [Laruelle, 2008; Sergunin, 2014]. Creativity is also produced by charismatic leaders at the level of "grand" diplomacy. For example, due to these qualities, President Vladimir Putin has managed to achieve recognition of his plan to destroy Syrian chemical weapons. The "New Silk Road" concept of another charismatic leader, Xi Jinping, was perceived as a global project of mutually beneficial Eurasian economic integration.

Despite their attractiveness, status theories still leave unanswered a number of important questions. For example, status indicators should be clarified. It is also important to clarify the question of when status becomes more important than material interests. In terms of content, the question of which instruments the state uses to change its status is of great importance. As for the internal aspects of the status policy, it is necessary to examine the extent to which domestic political institutions can influence the growth or reduction of the feeling of disrespect in society. These questions status theories have yet to answer.

\section{Theory of "Global Regionalism"}

The BRICS' uniqueness lies in the fact that it is not an ordinary international region representing a set of states that are close to each other and form a certain historical, economic, political and sociocultural community (or at least seek to create such a community). According to the theory of "new regionalism" [Lagutina, 2009; Lagutina, Vasilyeva, 2012; Acharya, 2014; Heininen, 2016; Hettne, Inotia, Sunkel, 1999; van Langenhove, 2011], the BRICS belongs to the category of so-called "global regions" which are based on functional, network, identity, multi-actor and multifactor principles rather than on geographic proximity. Such regions have a cross-cutting nature: they easily permeate various levels - local, regional and global - to create a completely different type of world politics [Avdokushin, Zharikov, 2013; Meena, 2015]. In addition to the BRICS, such global regions include, for example, the European Union, the Association of Southeast Asian Nations, the Mercado Común del Sur, the Eurasian Economic Union and the Arctic.

Supporters of the theory of global regionalism believe that during its existence, the BRICS has managed to form a common transnational agenda. Among the most important areas of cooperation of the BRICS countries are the following:

- improvement of the global financial system;

- development of industrial and commercial relations;

- energy security; 
- cooperation in the field of climate change and environmental protection;

- joint research projects;

- the fight against cyberterrorism, and;

- coordination of these countries' activities in international organizations, including the UN and its specialized agencies.

In support of this global agenda, the BRICS created a number of its own financial institutions - the New Development Bank with a capital of $\$ 100$ billion and a Contingent Reserve Arrangement ( $\$ 100$ billion as well).

In recent years, the Chinese have launched the New Silk Road (or One Belt One Road) project [Lagutina, Batur, 2016; Leksyutina, 2017]. At first, it was aimed at the development of a land transport corridor through the territory of Eurasia. It was then supplemented by sea routes from East Asia to Europe, both southern (through the Suez Canal) and northern (Northern Sea Route). In the end, the project has acquired a truly global dimension, incorporating the Pacific region and South America, where one of the BRICS members is located (Brazil).

At the same time, critics of the theory of global regionalism note that in the framework of the BRICS, a truly unified agenda has not yet emerged. With rare exceptions, most of the cooperative ties within the BRICS are bilateral, not multilateral. In addition, there are numerous differences between the members of this international group. Particularly, there are serious disagreements between India and China, including territorial disputes between them that regularly lead to direct military-political confrontation. Opponents of this theory believe that it is too early to speak of the BRICS as a whole community comparable with other integration entities. For this reason, the BRICS is not yet able to play a truly influential role in world politics and the global economy.

\section{Conclusion}

So, various IRTs offer their explanations of the very phenomenon of the BRICS, the motives for the behaviour of the countries in this group and the role that this integration forum plays in modern world politics and the global economy. Speaking about the relative value or explanatory power of each of these theories, the principle of complementarity seems to be the most acceptable, according to which each theory turns out to be productive depending on the research goal. Together, on the basis of an interdisciplinary approach, they form the foundation for studying complex political phenomenon such as the BRICS.

The newest IRTs tend to hold that, along with the pursuit of purely material and pragmatic interests (hedging financial and economic risks of the globalized era generated by the domination of a group of highly developed states, coordination of joint activities in the face of the geopolitical "drive" of the West and solving a number of common problems), the BRICS countries are actively using this integration association to strengthen their positions on the world stage and elevate their international statuses.

At the same time, members of the group apply various methods, from the strategy of mobility and competition to various types of creativity. These foreign policy strategies have had some effect, with the exception of Russia whose international reputation has suffered because of the Ukrainian crisis. In general, most of the BRICS countries have managed to create an image of themselves as constructive and peaceful states preferring coopera- 
tion to confrontation, respecting international rules and their international partners. Even for Russia, participation in BRICS has proved to be very useful from a reputational/status point of view. Since most of the countries in this group did not support western sanctions against Moscow, Russia managed not only to avoid complete international isolation, but also to actively influence international developments, both regionally and globally.

In general, the BRICS has managed to shape its image as an alternative model of world order based on principles and rules of interstate cooperation which exclude mandate, discrimination and hierarchy. It is too early to say that a fundamentally new type of international relations or international institution has been created within the framework of the BRICS, but, undoubtedly, some positive experience has emerged from this association. There is also no doubt that the activities of the BRICS will remain a subject of the closest attention from international relations theorists.

\section{References}

Toloraya G., Yurtaev V., Ajdrus I. (2016) BRICS: sotrudnichestvo v tselyakh razvitiya. Obrazovanie. Nauka. Biznes [BRICS: Cooperation for the Purposes of Development. Education. Science. Business]. Moscow: RUDN (in Russian).

Abdenur A.E. (2015) Brazil as a Rising Power: Coexistence Through Universalism. The BRICS and Coexistence: An Alternative Vision of World Order (C. de Coning, T. Mandrup, L. Odgaard (eds)). Abingdon: Routledge Taylor \& Francis Group, pp. 49-74.

Acharya A. (2014) The End of the American World Order. Cambridge and Malden: Polity Press.

Avdokushin E.F., Zharikov M.V. (2013) Strany BRICS v sovremennoi mirovoi ekonomike [BRICS Countries in the Contemporary World Economy]. Moscow: MAGISTR INFRA-M (in Russian).

BRICS (2017) BRICS Leaders Xiamen Declaration. Xiamen, China, 4 September. Available at: https:// brics2017.org/English/Headlines/201709/t20170908_2020.html (accessed 20 Ocober 2018)

Carafano J. (ed) (2015) U.S. Comprehensive Strategy Toward Russia. Washington DC: The Heritage Foundation.

Charap S., Shapiro J. (2014) A New European Security Order: The Ukraine Crisis and the Missing Post-Cold War Bargain. Paris: FRS.

Cheng D. (2016) China: Ready to Assume a Leadership Role? The Heritage Foundation. Available at: http://www.heritage.org/research/commentary/2016/3/china-ready-to-assume-a-leadership-role (accessed 12 February 2018).

Collins J. (2015) Daunting Challenges and Glimmers of Hope in Ukraine. Washington DC: Carnegie Endowment for International Peace. Available at: http://carnegieendowment.org/2015/11/20/dauntingchallengesandglimmersof hopeinukraine/im6s (accessed 12 August 2017).

Forsberg T., Heller R., Wolf R. (2014) Introduction. Communist and Post-Communist Studies, no 47, pp. 261-8. Fulquet G. (ed) (2015) The Rise and Fall of International Powers: An Assessment of the BRICS. Buenos Aires: FLACSO.

Glinkin S.P. (2014) Novoe napravlenie rossiyskoi vneshnei vneshneekonomicheskoi politiki - vzaimodeistvie $v$ BRICS [New Vector of Russia's Foreign and Foreign Economic Policy: Interaction in BRICS]. Moscow: RAS Institute of Economics (in Russian).

Granholm N., Malminen J., Persson G. (eds) (2014) A Rude Awakening: Ramifications of Russian Aggression Towards Ukraine. Stockholm: FOI.

Gronskaya N.E., Makarychev A.S. (2010) Ideya imperii i “myagkaya sila:” mirovoi opyt i rossiyskie perspektivy [Imperial Idea and "Soft Power:" World Experience and Russian Prospects]. Management Issues, no 10, pp. 22-27. (in Russian) 
Gupta S., Chatterjee S. (2015) Indian Foreign Policy and Coexistence: Continuity and Change. The BRICS and Coexistence: An Alternative Vision of World Order (C. de Coning, T. Mandrup, L. Odgaard (eds)). Abingdon: Routledge Taylor \& Francis Group, pp. 100-124.

Hansen F., Sergunin A. (2015) Russia, BRICS, and Peaceful Coexistence: Between Idealism and Instrumentalism. The BRICS and Coexistence: An Alternative Vision of World Order (C. de Coning, T. Mandrup, L. Odgaard (eds)). Abingdon: Routledge Taylor \& Francis Group, pp. 75-99.

Heininen L. (2016) Security of the Global Arctic in Transformation: Potential for Changes in Problem Definition. Future Security of the Global Arctic: State Policy, Economic Security and Climate (L. Heininen (ed)). Basingstoke: Palgrave Pivot.

Hettne B., Inotia A., Sunkel O. (1999) Globalism and the New Regionalism. London: Macmillan.

IBASE (2015) BRICS: New Configurations of Global Power. Instituto Brasileiro de Análises Sociais e Econômicas (IBASE). Rio: IBASE.

Kanet R. (2010) Russian Foreign Policy in the 21st Century. London and New York: Palgrave Macmillan.

Konyshev V.N., Kubyshkin A.I., Sergunin A.A. (2015) Zashita grazhdanskogo naseleniya v mirotvorcheskoi deyatel' nosti OON: problemy i perspektivy [Civilian Population' s Protection in the UN Peacekeeping Activities: Problems and Prospects]. National Interests: Priorities and Security, no 26, pp. 53-66 (in Russian).

Konyshev V.N., Nocen E., Sergunin A.A. (2017) Simvolicheskie i reputatsionno-statusnye strategii BRICS: problemy i vozmozhnosti [BRICS Symbolic and Reputational-Status Strategies: Problems and Opportunities]. Simvolicheskaya Politika. Vyp. 5: Politika Identichnosti [Symbolic Politics. Issue 5: Identity Politics] (O.Y. Malinova (ed)). Moscow: INION RAN, pp. 159-174 (in Russian).

Korshunov S.A. (2013) BRICS v sovremennom mire i interesy Rossii [BRICS in the Contemporary World and Russia's Interests]. World and Politics, no 1, pp. 44-7.

Kuhn U. (2015) Understanding Russia. Russian Analytical Digest, no 162, pp. 5-8.

Kuzmin V. (2013) New BRICS Reserve Pool to Fight Currency Shocks. Russia Beyond the Headlines, 11 September.

Lagutina M.L. (2009) Miropoliticheskie aspekty global noi stratifikatsii [World-Policy Aspects of Global Stratification]. St. Petersburg: St. Petersburg State University Press (in Russian).

Lagutina M.L., Batur A.G. (2016) "Novy Shelkovy Put:” Amerikanskaya strategiya v sovremennoi Evrazii ["New Silk Road:" American Strategy in the Present-Day Eurasia]. Eurasian Law Journal, vol. 7 , no 98, pp. 36-41. (in Russian)

Lagutina M.L., Vasilieva N.A. (2012) Global ny evraziysky region: opyt teoreticheskogo osmysleniya sotsial no-politicheskoi integratsii [The Global Eurasian Region: Theorizing Socio-Political Integration]. St. Petersburg: Technical University Press. (in Russian)

Larson D., Shevchenko A. (2010) Status Seekers: Chinese and Russian Responses to U.S. Primacy. International Security, vol. 34, no 4, pp. 63-95.

Laruelle M. (2008) Russian Eurasianism, An Ideology of Empire. Baltimore: John Hopkins University Press.

Leksyutina Y.V. (2016) Kitay v BRICS: pervy sredi ravnykh [China in BRICS: Primus Inter Pares]. Far Eastern Issues, no 5 (in Russian).

Leksyutina Y.V. (2017) Liderstvo v BRICS: prognozy i realii [Leadership in BRICS: Prognoses and Realities]. World Economy and International Relations, vol. 61, no 5, pp. 25-33. (in Russian)

Lenin V.I. (1970) Sobranie aktiva moskovskoi organizatsii RKP (b) 6 dekabrya 1920 g. Doklad o konstessiyakh [The Caucus Meeting of the RCP (b) Moscow Organization. 6 December 1920. Report on Concessions]. Omnibus Edition, 5th ed. Moscow: Politizdat. (in Russian)

Lukyanov F. (2011) BRICS Goes from Fantasy to Reality. Available at: https://eng.globalaffairs.ru/redcol/BRICS-goes-from-fantasy-to-reality-15169.

Mandrup T., Smith K. (2015) South Africa's "Diplomacy of Ubuntu:” An African Approach to Coexistence? The BRICS and Coexistence: An Alternative Vision of World Order (C. de Coning, T. Mandrup, L. Odgaard (eds)). Abingdon: Routledge Taylor \& Francis Group, pp. 149-70. 
Meena K. (2015) Regions, Regionalization and BRICS. R/evolutions: Global Trends and Regional Issues, vol. 3, no 1, pp. 18-42.

Midlarsky M. (1969) Status Inconsistency and the Onset of International Warfare. Evanston: Northwestern University.

Mikhailenko E.B. (2016) Al' ternativny regionalism BRICS [BRICS' Alternative Regionalism]. Proceedings of the Ural Federal University: Series 3, Social Sciences, vol. 11, no 3, pp. 194-206. (in Russian)

Nadkarni V., Noonan N.C. (eds) (2013) Emerging Powers in a Comparative Perspective: The Political and Economic Rise of the BRIC Countries. New York: Bloomsbury.

Neumann I. (2005) Russia As a Great Power. Russia As a Great Power. Dimensions of Security Under Putin (J. Hendeskog, V. Konnander, B. Nygren, I. Oldberg, C. Pursiainen (eds)). Abingdon: Routledge, pp. 13-28.

Neumann I. (2007) Russia As a Great Power. Journal of International Relations Development, vol. 11, no 2, pp. 128-51.

Nye J. (2013) What China and Russia Don't Get About Soft Power. Available at: http://www.foreignpolicy. com/articles/2013/04/29/what_china_and_russia_don_t_get_about_soft_power (accessed 12 February 2018).

Okuneva L.S. (2012) BRICS: problemy i perspektivy [BRICS: Problems and Perspectives]. Moscow: MGIMO MFA RF. (in Russian)

Onuf N. (2013) Making Sense, Making Worlds: Constructivism in Social Theory and International Relations. Abingdon: Routledge.

Organski A. F.K. (1958) World Politics. New York: Alfred and Knopf.

Panova V. (2013) BRICS: problemy vzaimodeistviya i potentsial sotrudnichestva [BRICS: Problems of Interaction and Cooperative Potential]. Observer, no 1, pp. 39-53 (in Russian).

Russian Gazette (1999) Stroitel' stvo novogo mirovogo poryadka [Building a New World Order]. Available at: http://www.rg.ru/prilog/es/0904/1.htm (accessed 12 August 2017). (in Russian)

Sergunin A. (2010) Suverenitet: evolutsiya kontsepta [Sovereignty: The Concept's Evolution]. POLITEKS, vol. 6, no 4, pp. 5-21. (in Russian)

Sergunin A. (2013) Bridging a (Mis)perceptional Gap: The EU's Eastern Partnership and Russian Policies in the Trans-Caucasus. Bilge Strateji, vol. 5, no 8, pp. 24-5.

Sergunin A. (2014) Has Putin the Pragmatist Turned into Putin the Ideologue? Vlaams Marxistisch Tijdschrift, vol. 48, no 2, pp. 68-9.

Sergunin A. (2016) Explaining Russian Foreign Policy Behavior: Theory and Practice. Stuttgart: IbidemVerlag.

Sergunin A. (2017) Russian Perceptions of the Ukrainian Crisis: From Confrontation to Damage Limitation? Neighbourhood Perceptions of the Ukraine Crisis from the Soviet Union into Eurasia? (G. Besier, K. Stoklosa (eds)). Abingdon: Routledge, pp. 41-54.

Sergunin A., Karabeshkin L. (2015) Understanding Russia’s Soft Power Strategy. Politics, vol. 35, no 3-4, pp. 347-63.

Simha R.K. (2013) Why Russia Prefers BRICS to Europe. Russia Beyond the Headlines. 8 October.

Smith H. (2014) Russia As a Great Power: Status Inconsistency and the Two Chechen Wars. Communist and Post-Communist Studies, no 47, pp. 355-63.

Stuenkel O. (2014a) Emerging Powers and Status: The Case of the First BRICS Summit. Asian Perspective, vol. 38, no 1, pp. 89-109.

Stuenkel O. (2014b) The BRICS and the Future of Global Order. Lanham: Lexington Books.

The Moscow Times (2014) Russia Says BRICS Development Bank Ready to Launch. 9 July. Available at: http://www.themoscowtimes.com/business/article/russia-saysbrics-development-bank-ready-tolaunch/503183.html (accessed 12 August 2017).

Toloraya G.D. (2011) BRICS: shans izmenit' miroporyadok? [BRICS: A Chance to Change the World Order?] The World of Change, no 3, pp. 136-52 (in Russian). 
Toloraya G.D. (2014) Problemy vyrabotki dolgosrochnoi strategii BRICS: rossiysky vzglyad [Making a Long-Term BRICS Strategy: The Russian Perspective]. Comparative Politics, vol. 14, no 1, pp. 37-46. (in Russian)

Toloraya G.D., Chukov R.S. (2016) Rasschityvat' li na BRICS? [Should We Rely on BRICS?] International Organisations Research Journal, vol. 11, no 2, pp. 97-112.

Tsygankov A. (2013) Moscow's Soft Power Strategy. Current History, vol. 112, no 756, pp. 259-64.

Tsygankov A. (2013) Vsesil' no potomu chto verno? [Omnipotent Because It's True?] Russia in Global Politics, no 12. Available at: http://www.globalaffairs.ru/number/Vsesilno-ibo-verno-16251 (accessed 12 February 2018) (in Russian).

van Langenhove L. (2011) Building Regions: The Regionalization of the World Order. Abingdon: Ashgate Publishing.

Wallace M. (1973) Alliance Polarization, Cross-Cutting and International War, 1815-1964: A Measurement Procedure and Some Preliminary Evidence. Journal of Conflict Resolution, vol. 17, no 4, pp. 575-604. 


\title{
БРИКС как предмет изучения теории международных отношений
}

\author{
А.А. Сергунин, Ф. Гао
}

Сергунин Александр Анатольевич - д.полит.н., профессор кафедры теории и истории международных отношений Санкт-Петербургского государственного университета; Российская Федерация, 19106, СанктПетербург, ул. Смольного, д. 1/3; E-mail: a.sergunin@spbu.ru

Гао Фей - профессор, заместитель президента и декан по академическим вопросам Китайского университета международных отношений; Китайская Народная Республика, 100037, Пекин, ул. Чжанлянь, д. 24; E-mail: fgao@cfau.edu.cn

В статье анализируются различные интерпретации БРИКС современными теориями международных отношений. В частности, рассматриваются теория изменения соотношения сил, концепции «мягкой силы» и мирного сосуществования, теория «глобального регионализма», а также статусные теории. Каждая из них дает свое объяснение как самому феномену БРИКС, так и той роли, которую это интеграционное объединение играет в современной системе международных отношений. Делается вывод, что каждая из этих теорий, несмотря на известную ограниченность, может обладать эвристической ценностью - в зависимости от поставленных целей и задач исследования, а также способов применения. В совокупности они создают междисииллинарную основу для изучения такого сложного феномена, как БРИКС.

Многие современные исследователи склонны считать, что, наряду с преследованием сугубо материальнопрагматических интересов, страны БРИКС активно используют это интеграционное объединение для укрепления своих позиций на мировой арене и повышения международного статуса.

Делается также вывод о том, что БРИКС преуспел в создании имиджа альтернативной модели мироустройства, основанной на принципах сотрудничества, взаимного уважения и баланса интересов, а не диктата, дискриминации и иерархии. Пока еще преждевременно утверждать, что в рамках БРИКС действительно был создан принципиально новый тип межгосударственных отношений или международного института. В то же время нет сомнений в том, что определенный позитивный опыт в рамках этого форума уже накоплен, а значит, БРИКС как институт имеет неплохие перспективы на будущее и представляет для теории международных отношений значительный интерес.

Ключевые слова: БРИКС; теория международных отношений

Для цитирования: Сергунин А.А., Гао Ф. (2018) БРИКС как предмет изучения теории международных отношений // Вестник международных организаций. Т. 13. № 4. С. 55-73 (на русском и английском языках). DOI: $10.17323 / 1996-7845-2018-04-03$

\section{Источники}

Авдокушин Е.Ф., Жариков М.В. (2013) Страны БРИКС в современной мировой экономике. М.: МАГИСТР ИНФРА-М.

Айдрус И.А., Толорая Г.Д., Юртаев В.И. (2016) Сборник материалов конференции «БРИКС: сотрудничество в целях развития». М.: РУДН.

Гронская Н.Э., Макарычев А.С. (2010) Идея империи и «мягкая сила»: мировой опыт и российские перспективы // Вопросы управления. № 10. С. 22-27.

Конышев В.Н., Кубышкин А.И., Сергунин А.А. (2015) Защита гражданского населения в миротворческой деятельности ООН: проблемы и перспективы // Национальные интересы: приоритеты и безопасность. № 26. С. 53-66. 
Конышев В.Н., Ноцень Э., Сергунин А.А. (2017) Символические и репутационно-статусные стратегии БРИКС: проблемы и возможности // Символическая политика. Вып. 5: Политика идентичности / под ред. О.Ю. Малиновой. М.: ИНИОН РАН. С. 159-174.

Коршунов С.А. (2013) БРИКС в современном мире и интересы России // Мир и политика. № 1. C. $44-47$.

Лагутина М.Л. (2009) Мирополитические аспекты глобальной стратификации. СПб.: Издательство Санкт-Петербургского государственного университета.

Лагутина М.Л., Батур А.Г. (2016) «Новый Шелковый путь»: американская стратегия в современной Евразии // Евразийский юридический журнал. № 7 (98). С. 36-41.

Лагутина М.Л., Васильева Н.А. (2012) Глобальный евразийский регион: опыт теоретического осмысления социально-политической интеграции. СПб.: Издательство Политехнического университета.

Лексютина Я.В. (2016) Китай в БРИКС: первый среди равных // Проблемы Дальнего Востока. № 5.

Лексютина Я.В. (2017) Лидерство в БРИКС: прогнозы и реалии // Мировая экономика и международные отношения. Т. 61. № 5. С. 25-33.

Ленин В.И. (1970) Собрание актива московской организации РКП(б). 6 декабря 1920 г. Доклад о концессиях // Полное собрание сочинений. 5-е изд. М.: Политиздат.

Михайленко Е.Б. (2016) Альтернативный регионализм БРИКС // Известия Уральского федерального университета. Сер. 3. Общественные науки. Т. 11. № 3. С. 194-206.

Глинкин С.П. (2014) Новое направление российской внешней и внешнеэкономической политики взаимодействие в БРИКС. М.: Институт экономики РАН.

Окунева Л.С. (2012) БРИКС: проблемы и перспективы. М.: МГИМО МИД РФ.

Панова В. (2013) БРИКС: проблемы взаимодействия и потенциал сотрудничества // Обозреватель. № 1. C. 39-53.

Сергунин А.А. (2010) Суверенитет: эволюция концепта // ПОЛИТЭКС. Т. 6. № 4. С. 5-21.

Российская газета (1999) Строительство нового мирового порядка. 4 сентября. Режим доступа: http:// www.rg.ru/prilog/es/0904/1.htm (дата обращения: 12.08.2017).

Толорая Г.Д. (2011) БРИКС: Шанс изменить миропорядок? // Мир перемен. № 3. С. 136-152.

Толорая Г.Д. (2014) Проблемы выработки долгосрочной стратегии БРИКС: российский взгляд // Сравнительная политика. Т. 5. № 1 (14). С. 37-46.

Толорая Г.Д., Чуков Р.С. (2016) Рассчитывать ли на БРИКС? // Вестник международных организаций: образование, наука, новая экономика. Т. 11. № 2. С. 97-112.

Цыганков А. (2013) Всесильно, потому что верно? // Россия в глобальной политике. № 12. Режим доступа: http://www.globalaffairs.ru/number/Vsesilno-ibo-verno-16251 (дата обращения: 12.02.2018).

Abdenur A.E. (2015) Brazil as a rising power: coexistence through universalism. The BRICS and Coexistence: An Alternative Vision of World Order (C. De Coning, T. Mandrup, L. Odgaard (eds.)). Abingdon: Routledge Taylor \& Francis Group. P. 49-74.

Acharya A. (2014) The End of the American World Order. Cambridge and Malden: Polity Press.

BRICS (2017) BRICS Leaders Xiamen Declaration. Xiamen, China, 4 September. Режим доступа: https:// brics2017.org/English/Headlines/201709/t20170908_2020.html

Carafano J. (ed.) (2015) U.S. Comprehensive Strategy toward Russia. Washington, DC: The Heritage Foundation.

Charap S., Shapiro J. (2014) A New European Security Order: The Ukraine Crisis and the Missing Post-Cold War Bargain. Paris: FRS.

Cheng D. (2016) China: Ready to Assume a Leadership Role? 10 March. Режим доступа: http://www.heritage. org/research/commentary/2016/3/china-ready-to-assume-a-leadership-role (дата обращения: 12.02.2018).

Collins J. (2015) Daunting Challenges and Glimmers of Hope in Ukraine. 20 November. Washington, DC: Carnegie Endowment for International Реace. Режим доступа: http://carnegieendowment.org/2015/11/20/ dauntingchallengesandglimmersofhopeinukraine/im6s (дата обращения: 12.08.2017). 
de Coning C., Mandrup T., Odgaard L. (2015) The BRICS and Coexistence: An Alternative Vision of World Order. Abingdon: Routledge Taylor \& Francis Group.

Forsberg T., Heller R., Wolf R. (2014) Introduction // Communist and Post-Communist Studies. № 47. P. 261-268.

Fulquet G. (2015) The Rise and Fall of International Powers: An Assessment of the BRICS. Buenos Aires: FLACSO.

Granholm N., Malminen J., Persson G. (2014) A Rude Awakening. Ramifications of Russian Aggression Towards Ukraine. Stockholm: FOI.

Grygas A. (2012) Legacies, Coercion and Soft Power: Russian Influence in the Baltic States // Chatham House Briefing Paper. August. Режим доступа: http://www.chathamhouse.org/sites/files/chathamhouse/public/ Research/Russia\%20and\%20Eurasia/0812bp_grigas.pdf (дата обращения: 12.02.2018).

Gupta S., Chatterjee S. (2015) Indian foreign policy and coexistence: continuity and change. The BRICS and Coexistence: An Alternative Vision of World Order. (C. De Coning, T. Mandrup, L. Odgaard. (eds)). Abingdon: Routledge Taylor \& Francis Group, pp. 100-124.

Hansen F., Sergunin A. (2015) Russia, BRICS, and peaceful coexistence: between idealism to instrumentalism. The BRICS and Coexistence: An Alternative Vision of World Order. (C. De Coning, T. Mandrup, L. Odgaard. (eds)). Abingdon: Routledge Taylor \& Francis Group. C. 75-99.

Heininen L. (2016) Security of the Global Arctic in Transformation - Potential for Changes in Problem Definition. Future Security of the Global Arctic. State Policy, Economic Security and Climate (L. Heininen (ed)). Basingstoke: Palgrave Pivot.

Hettne B., Inotia A., Sunkel O. (1999) Globalism and the New Regionalism. L.: Macmillan.

IBASE (2015) BRICS: New Configurations of Global Power. Instituto Brasileiro de Análises Sociais e Econômicas (IBASE). Rio: IBASE.

Kanet R. (2010) Russian Foreign Policy in the 21st Century. L.; N. Y.: Palgrave Macmillan.

Kuhn U. (2015) Understanding Russia // Russian Analytical Digest. No. 162. P. 5-8.

Kuzmin V. (2013) New BRICS reserve pool to fight currency shocks // Russia Beyond the Headlines. 11 September.

Langenhove L. van (2011) Building Regions: The Regionalization of the World Order. Abingdone: Ashgate Publishing.

Larson D., Shevchenko A. (2010) Status Seekers. Chinese and Russian Responses to U.S. Primacy // International Security. Vol. 34. No. 4. P. 63-95.

Laruelle M. (2008) Russian Eurasianism, an Ideology of Empire. Baltimore: John Hopkins University Press.

Lukyanov F. (2011) BRICS goes from fantasy to reality // Russia in Global Affairs. 17 April.

Mandrup T., Smith K. (2015) South Africa' s "diplomacy of ubuntu”: an African approach to coexistence? The BRICS and Coexistence: An Alternative Vision of World Order (C. De Coning, T. Mandrup, L. Odgaard. (eds)). Abingdon: Routledge Taylor \& Francis Group. Pp. 149-170.

Meena K. (2015) Regions, Regionalization and BRICS // Revolutions: Global Trends and regional issues. Vol. 3. No. 1. P. $18-42$.

Midlarsky M. (1969) Status Inconsistency and the Onset of International Warfare. Evanston: Northwestern University.

Nadkarni V., Noonan N.C. (2013) Emerging Powers in a Comparative Perspective: The Political and Economic Rise of the BRIC Countries. N. Y.: Bloomsbury.

Neumann I. (2007) Russia as a Great Power // Journal of International Relations Development. Vol. 11. No. 2. P. $128-151$.

Neumann I. (2005) Russia as a Great Power // Russia as a Great Power. Dimensions of Security Under Putin / J. Hendeskog, V. Konnander, B. Nygren, I. Oldberg, C. Pursiainen (eds). Abingdon: Routledge. P. 13-28.

Nye J. (2013) What China and Russia Don't Get About Soft Power. 29 April. Режим доступа: http:// www.foreignpolicy.com/articles/2013/04/29/what_china_and_russia_don_t_get_about_soft_power (дата обращения: 12.02.2018). 
Onuf N. (2013) Making Sense, Making Worlds. Constructivism in Social Theory and International Relations. Abingdon: Routledge.

Organski A.F.K. (1958) World Politics. N. Y.: Alfred and Knopf.

Sergunin A. (2013) Bridging a (mis)perceptional gap: the EU's Eastern Partnership and Russian policies in the Trans-Caucasus // Bilge Strateji. Vol. 5. No. 8. P. 24-25.

Sergunin A. (2016) Explaining Russian Foreign Policy Behavior: Theory and Practice. Stuttgart: Ibidem-Verlag. Sergunin A. (2014) Has Putin the Pragmatist Turned into Putin the Ideologue? // Vlaams Marxistisch Tijdschrift. Vol. 48. No. 2. P. 68-69.

Sergunin A. (2017) Russian Perceptions of the Ukrainian Crisis: From Confrontation to Damage Limitation? // Neighbourhood Perceptions of the Ukraine Crisis from the Soviet Union into Eurasia? / G. Besier, K. Stoklosa (eds). Abingdon: Routledge. P. 41-54.

Sergunin A., Karabeshkin L. (2015) Understanding Russia’s Soft Power Strategy // Politics. Vol. 35. No. 3-4. P. 347-363.

Simha R.K. (2013) Why Russia prefers BRICS to Europe // Russia Beyond the Headlines. 8 October.

Smith H. (2014) Russia as a great power: Status inconsistency and the two Chechen wars // Communist and Post-Communist Studies. No. 47. P. 355-363.

Stuenkel O. (2014a) Emerging Powers and Status: The Case of the First BRICS Summit // Asian Perspective. Vol. 38. No. 1. P. 89-109.

Stuenkel O. (2014b). The BRICS and the Future of Global Order. Lanham: Lexington Books.

The Moscow Times (2014) Russia Says BRICS Development Bank Ready to Launch. 9 July. Режим доступа: http://www.themoscowtimes.com/business/article/russia-saysbrics-development-bank-ready-tolaunch/503183.html (дата обращения: 12.08.2017).

Tsygankov A. (2013) Moscow’s Soft Power Strategy // Current History. Vol. 112. No. 756. P. 259-264.

Wallace M. (1973) Alliance Polarization, Cross-Cutting and International War, 1815-1964: A Measurement Procedure and Some Preliminary Evidence // Journal of Conflict Resolution. Vol. 17. No. 4. P. 575-604. 